\title{
The $\mathrm{CO}_{2}$ and $\mathrm{PM}_{2.5}$ levels in Downtown Vancouver at peak (5 p.m.) and off-peak (12 a.m.) hours
}

\author{
Oguz Erel ${ }^{1}$, Helen Heacock ${ }^{2}$ \\ 1 Lead Author, B.Tech Student, School of Health Sciences, British Columbia Institute of Technology, 3700 \\ Willingdon Ave, Burnaby, BC V5G 3H2 \\ 2 Supervisor, School of Health Sciences, British Columbia Institute of Technology, 3700 Willingdon Ave, Burnaby, \\ BC V5G $3 \mathrm{H} 2$
}

\begin{abstract}
The effects of air pollution and global warming on human health have reached a dangerous level and this situation has become a critical environmental concern all over the world. The aim of the study was to explore levels of $\mathrm{PM}_{2.5}$ and $\mathrm{CO}_{2}$ emitted from the combustion engines of the road vehicles. The reason for choosing $\mathrm{PM}_{2.5}$ as one of the variables in this study is that it easily penetrates the lungs alveoli and is transmitted to other body organs by blood circulation. Exposure to $\mathrm{PM}_{2.5}$ from a few hours to a few weeks can cause serious cardiovascular diseases (CVDs), including death. The longer the exposure, the higher the risk for cardiovascular mortality. On the other hand, decrease in $\mathrm{PM}_{2.5}$ levels reduces cardiovascular mortality. Studies also show that $\mathrm{PM}_{2.5}$ is associated with diabetes, hypertension, and heart failure. The reason for choosing $\mathrm{CO}_{2}$ was its being as one of the six greenhouse gases leading to the climate change or global warming that threatens human health all over the world. Traffic emissions are the major source for both $\mathrm{PM}_{2.5}$ and $\mathrm{CO}_{2}$. That is why to understand the extent of the $\mathrm{PM}_{2.5}$ and the $\mathrm{CO}_{2}$ emissions from fossil fuel burning and thus their impact on human life is important.
\end{abstract}

Studies show that while air pollution is high during peak hours, it is lower during off-peak hours. Moving from this fact, the discrepancies between peak and off-peak hours readings of the $\mathrm{PM}_{2.5}$ and $\mathrm{CO}_{2}$ levels, which were measured in Vancouver Downtown during 30 consecutive days, were observed.

Air particulates $\mathrm{PM}_{2.5}$ were measured with the Dust Trak aerosol monitor and $\mathrm{CO}_{2}$ levels with $\mathrm{Q}$ Trak monitor. Results showed a statistically significant difference in the median concentration of $\mathrm{PM}_{2.5}$ between 5 p.m. and 12 a.m. $(p=0.018)$. However there was no statistically significant difference in the median concentration of $\mathrm{CO}_{2}$ between 5 p.m. and 12 a.m. $(p=0.84)$.

Measures to reduce air pollution, particularly through reducing $\mathrm{PM}_{2.5}$ and $\mathrm{CO}_{2}$ levels, especially in urban settings, can help reduce the risks of global warming $\left(\mathrm{CO}_{2}\right.$ effect) and have positive effect on public health issues by preventing or reducing the risks of occurrence of many diseases, and their fatal consequences in some instances, caused or triggered by exposure to air pollution. Both national governments and international agencies should support the scientific research the results of which will inform the public health policies and regulations that will promote cleaner air and thus healthier societies by both implementing some enforcement measures and educating the public on the risks of air pollution and global warming and the relevant and available remedies. This study has been carried out to contribute to the efforts made to this end.

Keywords: $\mathrm{PM}_{2.5}, \mathrm{CO}_{2}$, air pollution, emissions, greenhouse gases, global warming, traffic

\section{Introduction}

Recent scientific studies provides a growing body of evidence addressing the relationship between people's exposure to ambient air pollution and a wide range of health problems, especially in the areas characterized by economic growth and increased urbanization. (D'Amato et al. 2013) states that economic and industrial growth in the $20^{\text {th }}$ century caused an enormous increase in emissions of air pollutants, making air quality an environmental problem for most of Europe and North American countries; and as time goes on, more and more regions in the world are affected. 
"The most abundant components of air pollution in urban areas are nitrogen dioxide $\left(\mathrm{NO}_{2}\right)$, ozone, and particulate matter (PM). With its particulate and gaseous emissions, road traffic is the main contributor to air pollution in most urban areas in both developed and less-developed countries (D'Amato et al. 2013). Traffic-related air pollution, i.e. air pollution from the combustion of fossil fuels, has several public health effects ranging from eye irritation to deaths, and the situation is getting worse (Cohen et al. 2005).

Ambient particulate matter has been listed as one of the ten leading risk factors for cardiovascular diseases, and acute and chronic upper and lower respiratory and allergic diseases, including asthma, chronic obstructive pulmonary disease (COPD), pneumonia, tuberculosis, and even lung cancer. (Fajersztajn, Veras, Barrozo, \& Saldiva 2013). Research on particular matter suggests that the particle size affects the accumulation of the particles in the respiratory tract and thus the extent of the harm they would inflict upon one's health (Fenger \& Tjell 2009): fine particulate matter, i.e. $\mathrm{PM}_{2,5}$, is more easily placed in the lungs and does greater harm to the health than $\mathrm{PM}_{10}$ (Huang et al. 2008).

Another environmental concern is the accumulation of greenhouse gases, particularly $\mathrm{CO}_{2}$ and $\mathrm{N}_{2} \mathrm{O}$, in the Earth's atmosphere which causes global climate change. In parallel to the increase in the concentration of these gases, the average global temperature gradually increases, leading to increasing public health-related problems, particularly in developing countries which have scarce resources to respond and cope with the climate change (Burt, Orris, \& Buchanan 2013).

As $\mathrm{CO}_{2}$ constitutes only a very small percentage of the atmosphere $(0.040 \%)$, some people ignore its importance as a major heat-trapping substance, but Global Warming Potentials (GWPs) are defined relative to $\mathrm{CO}_{2}$ (Farmer \& Cook 2013). In crowded areas, especially in urban settings, traffic emissions are a major source of greenhouse gases. The main substance of fossil fuel burning is $\mathrm{CO}_{2}$, which has both adverse effects on the local health and the environment and adverse global effects on the chemistry of atmosphere and the climate (Popa et al. 2014).

Although technological advances in the automobile industry have improved the efficiency of the $19^{\text {th }}$ century's combustion engines of the motorized vehicles, and thus reduced the air pollution, particularly in Europe and North America, the increase in the number of vehicles due to increasing population and the resulting slowed down traffic are counterbalancing the preventive actions taken (Fajersztajn et al. 2013).

This study deals with the possible adverse health effects of transport by exploring $\mathrm{PM}_{2,5}$ and $\mathrm{CO}_{2}$ concentrations emitted from the motor vehicles in urban settings to see if the monitored amounts exceed the maximum acceptable concentration limits set by the provincial government of British Columbia.

Governments use the scientifically proven evidences to develop environmental policies to control air pollution (Cohen et al. 2005) and reduce greenhousegas emission, thus the author of this research hopes to contribute to the available scientific knowledge and growing body of evidence on the association of the traffic-related air pollution and greenhouse gases with certain diseases and mortality rates.

\section{Literature Review}

The objective of the study was to probe the impacts of diesel and gasoline engines of motor vehicles on air pollution in urban settings, and Vancouver in the present study. One of the major sources of air pollution is combustion engines: from the smallest to the biggest engines (e.g. marine engine), they all are air pollutants. Apart from road vehicles with combustion engines, off road vehicles, aircrafts, ships, and trains significantly contribute to air pollution. Among the combustion engines, gasoline and diesel engines, which are internal combustion engines, are the most significant pollutants (Fenger \& Tjell 2009).

Pollutants emitted particularly from automobiles may significantly vary during the day. The emission is the highest during morning and evening rush hours (Environmental Health UK 2014).

By interacting with other chemicals, the pollutants that were emitted from different sources form new compounds. The researchers believe that when the windblown natural dust from dry soil and roads blends with these combustion particles, the new compound gives more harm to human health (Environmental Health UK 2014).

\section{Particulate Matters (PMs) and their Health Effects}

PM refers to all airborne liquid and solid particles. These particles have different physical and chemical characteristics depending on the sources they are emitted from. PM has two types: $\mathrm{PM}_{10}$ and $\mathrm{PM}_{2.5}$; the former contains mainly materials derived from soil and minerals, and the latter, which is usually resulted 
from anthropogenic activities, contains many organic and inorganic compounds (Woolsey 2013; Fenger \& Tjell 2009). Traffic is one of the main sources of PM (Fajersztajn et al. 2013), i.e. emissions from motor vehicles.

Unlike the large-scale industrial sources of air pollution, traffic emissions are most likely easier to be exposed because of close proximity. People living and working in urban settings and especially attending schools or working near major roads in these areas are highly exposed to traffic-related air pollutants during their commuting on roadways where air pollution is concentrated. The time and the mode of transport is the key determinant of exposure. Related studies show that while cyclists have the highest doses, electric bus riders have the lowest. The higher the air pollution concentration and the closer the proximity to the source of pollution, the higher the dose of exposure is. (Laumbauch \& Kipen 2012). Thus, the exposure to the traffic-related air pollutants, through inhaling them, varies in accordance with (a) traffic density, (b) proximity to the source of air pollutants, (c) time, (d) activity pattern/mode of transportation.

The analyses estimate that $\mathrm{PM}_{2,5}$ causes about " $3 \%$ of mortality from cardiopulmonary disease, about $5 \%$ of mortality from cancer of trachea, bronchus, and lung, and about $1 \%$ of mortality from acute respiratory infections in children under $5 \mathrm{yr}$, worldwide." This amounts to about $1.2 \%$ premature deaths (Cohen et al. 2005).

It has been reported that in big cities where air pollution is relatively high, the cases of bronchitis, pneumonia, lower lung function, cardiovascular disease, and childhood asthma are more common than in cities with better air quality. Air pollution especially rising from the traffic causes fatal health problems. Deaths due to the respiratory and cardiovascular diseases are believed to be 5-10 times more than the deaths caused by the traffic accidents. It even triggers premature and low weight birth babies (Fenger \& Tjell 2009).

Those who live close to heavy traffic areas are more exposed to the risk of cancer due to the carcinogenic components of traffic emissions, for these particles contain very toxic substances such as polyaromatic hydrocarbons, dioxin, and heavy metals. By causing irritation and/or giving harm to the cells in the respiratory tract and lungs, these particles also have an intrinsic toxic effect. Moreover, these chemical substances are carried over to other body organs by blood circulation (Fenger \& Tjell 2009).

\section{Diseases Caused By PMs:}

\section{Air Pollution and Pulmonary Effects}

1.1 Pulmonary Diseases in Children and Childhood Asthma: Long-term studies show that there is strong evidence that associates ambient PM with lung function, lung development, and respiratory symptoms in children (Ruckerl, Schneider, Breitner, Cyrys \& Peters 2011). Asthma is the most common chronic disease in children, which is the result of a complex connection between an individual's genetic propensity and exposures to environmental pollution, including Environmental Tobacco Smoke (ETS) and traffic-related air pollution; however, their role in the development of Asthma is still uncertain (Franklin \& Kusel 2013).

1.2 Adults Asthma: Although recent database on the association between asthma in adults and trafficrelated air pollution is less robust, a role for roadway traffic still persists (Laumbauch \& Kipen 2012).

1.3 Chronic Obstructive Pulmonary Disease $(C O P D)$ : Studies have shown that long-term exposure to increased traffic-related $\mathrm{PM}_{2.5}$ air pollution is associated with an increased risk of COPD hospitalization and mortality (Gan, FitzGerald, Carlsten, Sadatsafavi \& Brauer 2013).

1.4 Lung Cancer: There is a strong link between the lung cancer and prolonged exposure to the PM or gaseous component of air pollution. Recent studies show that across the world, $8 \%$ of lung cancer deaths can be associated to exposure to $\mathrm{PM}_{2,5}$, and if human-generated fine particles are considered, this number might be higher. Scientific evidence about the link between the exposure to air pollution and an increased risk of other cancer types such as breast and urinary tract cancers is growing as well (Fajersztajn et al. 2013).

1.5 Tuberculosis: Although the recent database does not provide any evidence between traffic-related air pollution and tuberculosis, the findings show that particulate matters and diesel exhaust particles impair "macrophage function" in animals, which suggests that the same can apply to the humans. Although traffic-related air pollution has significant adverse effects on pulmonary diseases, diseases caused by this major factor can be prevented if the risks of exposure to traffic-related air pollutants are reduced. On the higher level, reducing the effects of traffic-related air pollution on pulmonary functions requires both public policy and individuals' awareness of the problem. 
"Consensus standards" acknowledge the impact of air pollutants in the prevention and management of asthma and COPD and recommend that clinicians advise patients to become aware of the risks of exposure to air pollution and the ways to avoid it, e.g. avoiding exercising or cycling near busy roadways to reduce exposure to traffic-related air pollution (Laumbauch \& Kipen 2012).

\section{Air Pollution and Cardiovascular Effects}

Recent epidemiological studies have led to a higher recognition of a strong association between trafficrelated air pollution exposure, and particularly acute $\mathrm{PM}_{2.5}$ exposures (over a few hours to weeks), and increased daily cardiovascular mortality and morbidity, including myocardial infarctions and ventricular fibrillation (Brook et al. 2010; Dockery 2001). As the exposure period gets longer, the extent of the risk of mortality increases. Exposure to $\mathrm{PM}_{2,5}$ was also reported as one of the causes of increased heart rate, decreased heart rate variability, and increased cardiac arrhythmias (Brook et al. 2004; Dockery 2001).

Most recent studies show that the mortality rate in cardiovascular diseases triggered or caused by both short- and long-term PM exposure is higher than that in PM triggered pulmonary diseases (Brook et al. 2010).

\section{Air Pollution and Infant Mortality}

Some solid evidence of the relationship between air pollution and infant mortality has been provided in WHO's 2005 report. The report concluded that the primary reason of the mortality was the respiratory deaths in the post neonatal period (Ruckerl et al. 2011). Fajersztajn et al. (2013) argue that "exposure to outdoor air pollution is expected to become the top environmental cause of premature mortality globally by 2050 , overtaking malaria and water quality, which are traditional environmental risks for premature deaths."

It should be added that studies addressing the association between infant mortality and air pollutions constitute a new research field, and the conclusions drawn should be used carefully.

As Laumbach and Kipen maintain (2012), public policy can promote or enforce engineering solutions towards reducing emissions from vehicles. Public health and regulatory approaches to vehicle emissions should be seen as an opportunity toward health improvement on a public scale.

\section{$\mathrm{CO}_{2}$ and Its Health Effects}

Climate change/global warming, which increasingly threatens human health all over the world and particularly in underdeveloped and developing countries, results from the increased concentration of six greenhouse gases: water vapor $\left(\mathrm{H}_{2} \mathrm{O}\right)$, Carbon dioxide $\left(\mathrm{CO}_{2}\right)$, Methane $\left(\mathrm{CH}_{4}\right)$, Nitrous oxide $\left(\mathrm{N}_{2} \mathrm{O}\right)$, Ozone $\left(\mathrm{O}_{3}\right)$, and CFCs.

Greenhouse gases were not at a threatening level in the atmosphere until the Industrial Revolution beginning in the middle of the $18^{\text {th }}$ century. With the Industrial Revolution, $\mathrm{CO}_{2}, \mathrm{CH}_{4}$, and $\mathrm{N}_{2} \mathrm{O}$ started to accumulate in higher concentrations reaching to a health threatening level by early $21^{\text {st }}$ century. There is no doubt that human actions have caused significance increase in the level of the concentration of the greenhouse gases (Farmer \& Cook 2013).

Being the centers of economic and social activities, urban settings are significant sources of greenhouse gas emissions and in turn they are exposed to higher risks of climate change. The climate is warming due to "anthropogenic emissions of greenhouse gases, particularly carbon dioxide $\left(\mathrm{CO}_{2}\right)$ from fossil fuel combustion" (Montzka, Dlugokencky \& Butler 2011). According to Bulkeley (2013), cities and towns produce over $70 \%$ of global energy-related $\mathrm{CO}_{2}$ emissions. The challenges of climate change in the urban settings urge essential changes in urban politics, economics, society and infrastructures.

One of the major sources of $\mathrm{CO}_{2}$ in populated regions is road traffic. While the emissions of most greenhouse gases from traffic are difficult to compute and they vary depending on technology, vehicle type, and driving conditions, $\mathrm{CO}_{2}$ can be calculated accurately from fuel consumption data as its emission rate is "relatively constant as it depends directly on the quantity of fuel burnt" (Popa et al. 2014).

Increase in the amount of $\mathrm{CO}_{2}$ in air causes both blood acidification and an increase in the rate and depth of breathing. Acid base regulation in the bodies of those who have been exposed to $\mathrm{CO}_{2}$ for a long time is distorted and thus the calcium mechanism in bones is adversely affected. Due to high $\mathrm{CO}_{2}$ level (7000 ppm), "acidosis" has been observed in those who stayed in a submarine for a few weeks. That's why Health Canada defined the exposure limit as high as $3500 \mathrm{ppm}$ to avoid calcium release from the bones under similar conditions due to the acidosis (NCCEH 2014). 
Reducing the warming effect of greenhouse gases, and particularly of $\mathrm{CO}_{2}$, is possible with the substantial reduction of the greenhouse gas emissions in main sectors (Montzka et al. 2011). such as household energy, urban land transport, food and agriculture, and electricity generation. Lower carbon transport (public transport, active transport, or carpooling), for instance, will reduce air pollution and injury risks and increase physical activity, which will have positive effects on main health outcomes such as ischemic heart disease, cerebrovascular disease, dementia, breast cancer, lung cancer, colon cancer, diabetes, depression, and road traffic injuries. Besides its benefits for health, affordable and clean energy can also help governments reduce poverty and support development (Haines et al. 2009).

Once the automobile industry introduced the catalytic converters in cars, emissions of some gases from the exhaust of the combustion engines have been considerably reduced. Recent emission standards and advances in vehicle technology all over the world have further decreased the emissions of the harmful gases (Popa et al. 2014).

Policies to reduce greenhouse-gas emissions that governments need to develop collectively to prevent their adverse health consequences should address and promote the followings (Haines et al. 2009):

(i) Increased active transport (walking and cycling).

(ii) Increased public transport, i.e. less privatecar use in urban areas.

(iii) Reduced consumption of animal products in high-consumption areas.

(iv) Generation of electricity from renewable or other low-carbon sources rather than from fossil fuels, particularly coal.

\section{Air Pollution Regulations}

There are air pollution regulations that control emissions of the pollutants and establish emission guidelines, including recommended limits on pollutants. Some relevant information from these regulations is as follows:

(i) In Canada, 24-hour average $\mathrm{PM}_{2.5}$ criterion is $30 \mu \mathrm{g} / \mathrm{m}^{3}$ and in $\mathrm{BC}$ it is $25 \mu \mathrm{g} / \mathrm{m}^{3}$ (BC Air Quality Objective 2014).

(ii) ACGIH (American Conference of Governmental Industrial Hygienists) recommends $5000 \mathrm{ppm} \mathrm{CO}_{2}$ TLV-TWA and 30000 ppm $\mathrm{CO}_{2}$ TLV-STEL (NCCEH 2014). (iii) Metro Vancouver is entitled to enforce the air emissions by the Environmental Management Act -Part 3, Section 31 (Coccola 2014). According to Part 6, Section 74 (1) (d) of the Environmental Management Act 2014, "the Lieutenant Governor in Council may make regulations for the purpose of preventing and reducing emissions from new motor vehicles and from engines" (Environmental Management Act 2014).

(iv) The fuel emissions from the motor vehicles are regularized according to the Cleaner Gasoline Regulation (B.C. Reg.498/95); and compliance requirements for gasoline are defined in Part 1. People dealing with gasoline (distributors and purchasers) should adhere to these requirements (Cleaner Gasoline Regulation 2014).

(v) Greenhouse Gas Reduction Standards (Vehicle Emissions Standards) Act enforces requirements for motor vehicles to meet certain Greenhouse Gas emissions standards (Greenhouse Reduction Act 2014).

(vi) Canadian Environmental Protection Act, 158 (a) and (b), gives enforcement power to the Minister to prevent or reduce the effects of vehicles, engines or equipment on air pollution. According to the Act, the Minister may conduct or undertake any research studies, evaluations, and development programs that s/he considers necessary to reduce the adverse effects of emissions from vehicles, engines or equipment on the air, energy conservation and the environment. (Canadian Environmental Protection Act 2014).

\section{Major Roles of Health Authorities and Agencies}

\section{Major roles of EHOs in regard to air pollution:}

(i) Monitoring and helping reduce the pollution levels in a local area.

(ii) Educating the public and enforcement of the air quality regulations.

(iii) Contributing to provincial responses to environmental health emergencies.

(iv) Co-ordinating the health component of environmental risk assessments.

(v) Developing related legislations (EH Manitoba 2014). 


\section{Major roles of Policy Makers and other Professional Agencies}

Actions that need to be taken by several groups to reduce greenhouse-gas emission in transport sector can be summarized as follows (Haines et al. 2009).

(i) Policy makers should consider health benefits of reduced greenhouse gases and prioritize mitigation strategies.

(ii) Health policy makers should promote and support policies to achieve low greenhousegas emissions.

(iii) Health professionals should support policies to mitigate greenhouse-gas emissions while promoting education on this topic in education institutions and the wider community.

(iv) Research funders should increase funding for interdisciplinary collaboration and promote strategies and policies for low greenhouse-gas emissions in their allocation of funding.

All of the above groups should ensure that the people in their working environment are encouraged to reduce their personal greenhouse-gas emissions, including through increased active transport.

\section{Purpose of Study}

The study was designed primarily to measure the levels of $\mathrm{PM}_{2.5}$ and $\mathrm{CO}_{2}$, which are emitted from the combustion engines of the road vehicles, at rush hours (5 p.m.) and quieter times (12 a.m.), and to compare results by time. The aim was to reflect the extent of the exposure, in the light of the max allowable concentrations specified by the BC government, and to evaluate the public health hazard of these substances due to the exposure to them. The ultimate aim of the study is to contribute to the scientific evidence that (a) reveals the association of air pollution with respiratory, pulmonary, and cardiovascular diseases and their fatal consequences in some instances and (b) informs public health practice and policies.

\section{Methods}

\section{Site Description}

The $\mathrm{CO}_{2}$ and $\mathrm{PM}_{2.5}$ concentrations were monitored at peak (5 p.m.) and off-peak (12 a.m.) hours. Air sampling was carried out at the UBC Robson Square in Downtown Vancouver.

\section{Site Address and Coordinates}

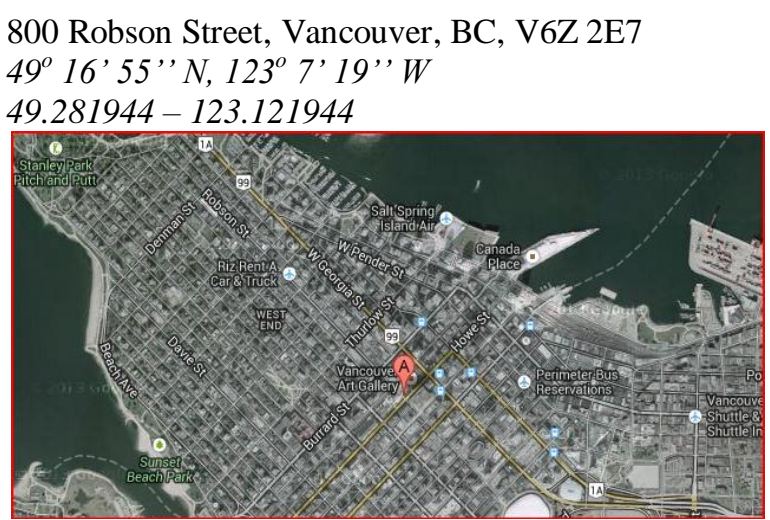

Figure 1: Location of sampling site (Google Earth)

This place is situated in an area of dense traffic and surrounded by high-rise buildings, and Lower Fraser Valley T001 Air Quality Network Station is located in this area. This was the main reason to choose this site for monitoring the air quality in Downtown Vancouver.

\section{Description of Materials}

Model 8550 Q-Trak Monitor was used for monitoring $\mathrm{CO}_{2}$ level during the study and Model 8520 DustTrak Aerosol Monitor was used for monitoring $\mathrm{PM}_{2.5}$ during the study.

\section{Description of Methods}

\section{$\mathrm{CO}_{2}$ Monitoring by Q-Trak Model 8550:}

Non dispersive infrared (NDIR) technology has been used for $\mathrm{CO}_{2}$ detection. NDIR technology is based on the Infra Red light absorption by the $\mathrm{CO}_{2}$ molecules at $4.26 \mu \mathrm{m}$ wavelength. High level of $\mathrm{CO}_{2}$ molecules absorbs more infrared light. The light density is absorbed by specific IR filter and reaches to the light detector for reading. While $\mathrm{CO}_{2}$ concentration increases, the intensity of IR light decreases.

The use of Q-Trak is very straightforward. On/off button and the $\mathrm{CO}_{2}$ key are the only buttons used when measuring $\mathrm{CO}_{2}$. After the instrument was turned on and stabilized for 5 minutes, the $\mathrm{CO}_{2}$ key was pressed to display $\mathrm{CO}_{2}$ readings. Concentration readings were displayed in $\mathrm{ppm}$. Reading time was set for 1 minute (Q-Trak 2014). Results were recorded on an MS Excel spreadsheet.

\section{PM 2,5 Monitoring by DustTrak Model 8520:}

Laser technology has been used for air particulates detection. Air particulates deflect the light, and the light density is captured by the detector. More particles scatter more laser light. Amount of the light 
is determined by the laser light detector (Woodgears 2014).

The use of DustTrak is very straightforward. On/off button and the "Sample" key are the only buttons used when measuring $\mathrm{PM}_{2,5}$. After $2.5 \mu \mathrm{m}$ nozzle was installed to the inlet, the instrument was turned on, waited for self-check to complete, then the "SAMPLE" key was pressed. Once sampling was completed, instrument scrolled through statistics. Reading time was set for 1 minute (DustTrak 2014). Results were recorded on an MS Excel spreadsheet.

\section{Reliability and Validity of Measures}

Air sampling tests were carried out once the calibration of the instruments was done. Air sampling monitor tests were done with duplicate readings and the average reading value was determined as a test result.

The fact that the Air Sampling Station is located in Vancouver Downtown provides some justification for the appropriateness of the area for air sampling in this study.

Q-Trak Model 8550 's accuracy is $\pm 3 \%$ of reading \pm $50 \mathrm{ppm}$ at $25^{\circ} \mathrm{C}$ and response time in 20 seconds.

DustTrak 8520 's sensor resolution is $1 \%$ of reading or $0.001 \mathrm{mg} / \mathrm{m}^{3}$ seconds (Enviro-Equipment 2014).

\section{Results}

\section{Statistical Analysis}

The data relating to $\mathrm{CO}_{2}$ and $\mathrm{PM}_{2.5}$ concentrations are numerical, continuous and the units are $\mathrm{ppm}$ and $\mu \mathrm{g} / \mathrm{m}^{3}$, respectively.

Descriptive Statistics of $\mathrm{CO}_{2}$ and $\mathrm{PM}_{2.5}$ are displayed below. Inferential Statistics will follow.

\section{Descriptive Statistics}

Table 1. Descriptive Statistics of $\mathrm{CO}_{2}$

\begin{tabular}{|c|c|c|c|c|c|c|c|c|}
\hline $\mathbf{C O}_{\mathbf{2}}$ & $\mathbf{N}$ & Range & $\begin{array}{c}\text { Minimum } \\
(\mathbf{p p m})\end{array}$ & $\begin{array}{c}\text { Maximum } \\
(\mathbf{p p m})\end{array}$ & $\begin{array}{c}\text { Mean } \\
(\mathbf{p p m})\end{array}$ & $\begin{array}{c}\text { Standard } \\
\text { Error }\end{array}$ & $\begin{array}{c}\text { Standard } \\
\text { Deviation }\end{array}$ & Variance \\
\hline $\mathrm{CO}_{2}$ 5 p.m. & 30 & 99 & 364 & 463 & 393.80 & 5.220 & 28.589 & 817.338 \\
$\mathrm{CO}_{2}$ 12 a.m. & 30 & 72 & 360 & 432 & 390.73 & 3.558 & 19.488 & 379.789 \\
\hline
\end{tabular}

Table 2. Descriptive Statistics of $\mathbf{P M}_{2.5}$

\begin{tabular}{|c|c|c|c|c|c|c|c|c|}
\hline $\mathbf{P M}_{2.5}$ & $\mathbf{N}$ & Range & $\begin{array}{c}\text { Minimum } \\
\left(\boldsymbol{\mu g} / \mathbf{m}^{\mathbf{3}}\right)\end{array}$ & $\begin{array}{c}\text { Maximum } \\
\left(\boldsymbol{\mu g} / \mathbf{m}^{\mathbf{3}}\right)\end{array}$ & $\begin{array}{c}\text { Mean } \\
\left(\boldsymbol{\mu g} / \mathbf{m}^{\mathbf{3}}\right)\end{array}$ & $\begin{array}{c}\text { Standard } \\
\text { Error }\end{array}$ & $\begin{array}{c}\text { Standard } \\
\text { Deviation }\end{array}$ & Variance \\
\hline $\mathrm{PM}_{2.5}$ 5 p.m. & 30 & 75 & 3 & 78 & 15.63 & 2.893 & 15.843 & 250.999 \\
$\mathrm{PM}_{2.5} 12 \mathrm{pm}$ & 30 & 23 & 0 & 23 & 8.07 & 1.075 & 5.889 & 34.685 \\
\hline
\end{tabular}

Table 3. Comparison of $\mathrm{CO}_{2}$ Means

ppm Comparison of CO2 Means

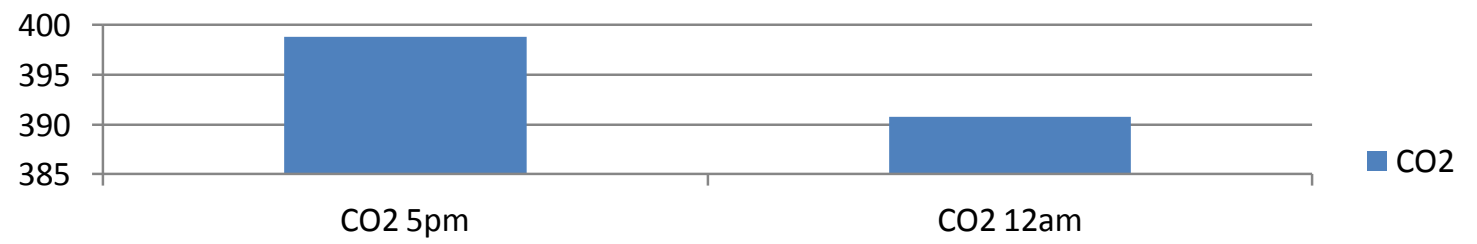

Time 
Table 4. Comparison of $\mathrm{PM}_{2.5}$ Means

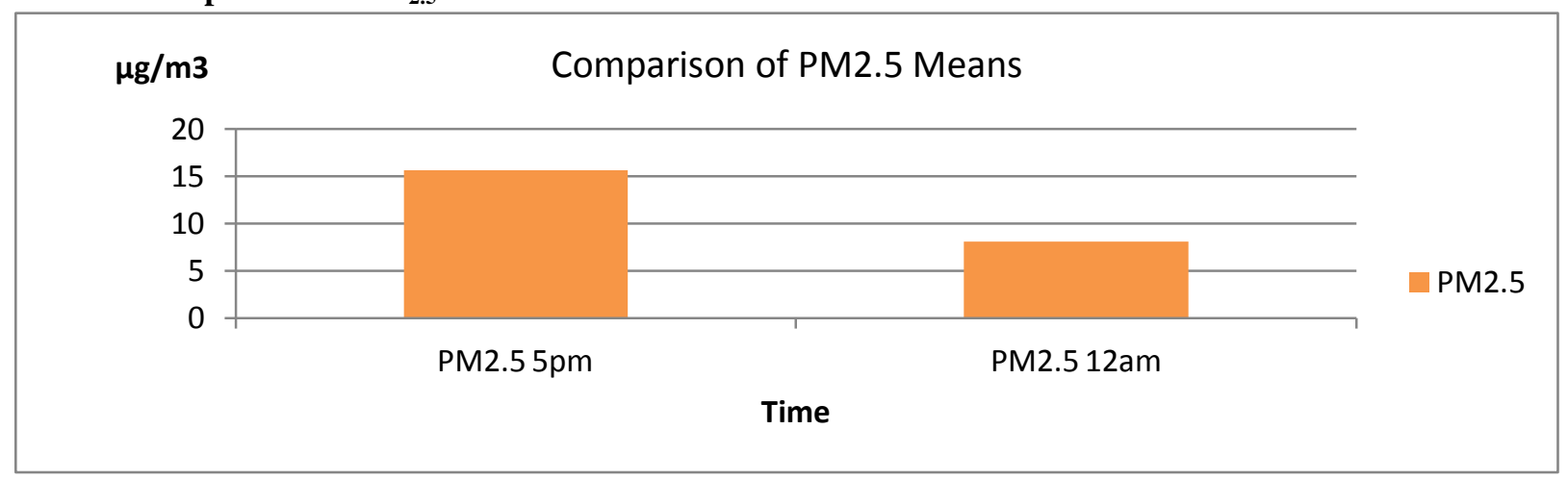

\section{Inferential Statistics}

\section{$\mathrm{CO}_{2}$ Levels}

In this study, following hypotheses were tested:

\section{Null Hypothesis:}

$\boldsymbol{H}_{\boldsymbol{0}}$ There is no difference between peak and off-peak hours $\mathrm{CO}_{2}$ levels.

\section{Alternative Hypothesis:}

$\boldsymbol{H}_{\boldsymbol{a}}$ There is a difference between peak and off-peak hours $\mathrm{CO}_{2}$ levels.

For testing whether there is a statistically significant difference in the median concentration of $\mathrm{CO}_{2}$ between 5 p.m. and 12 a.m., the author decided to perform Mann-Whitney $U$ test. The reason of choosing this test was the unequal distribution of the recorded data. The results show for a two-tailed test, a $p$-value of 0.84 , and for a one-tailed test, a $p$-value of 0.58 . At $5 \%$ significance level, there is no statistically significant difference in the median concentration of $\mathrm{CO}_{2}$ between 5 p.m. and 12 a.m., thus "do not reject $H_{0}$."

Since Mann-Whitney $U$ test does not provide the power, the author decided to perform two-sample $t$ test assuming unequal variance (Aspin-Welch Unequal-Variance test), and the power was found to be 0.076 .

\section{$P M_{2.5}$ Levels}

In this study, following hypotheses were tested:

\section{Null Hypothesis:}

$\boldsymbol{H}_{\boldsymbol{0}}$ There is no difference between peak and off-peak hours $\mathrm{PM}_{2.5}$ levels.

\section{Alternative Hypothesis:}

$\boldsymbol{H}_{\boldsymbol{a}}$ There is a difference between peak and off-peak hours $\mathrm{PM}_{2.5}$ levels.

For testing whether there is a statistically significant difference in the median concentration of $\mathrm{PM}_{2.5}$ between 5 p.m. and 12 a.m., the author decided to perform Mann-Whitney $U$ test. The reason of choosing this test was the unequal distribution of the recorded data. The results show for a two-tailed test, a $p$-value of 0.018 , and for a one-tailed test, a $p$-value of 0.009. Either way, and at 5\% significance level, we have sufficient evidence to conclude that there is a statistically significant difference in the median concentration of $\mathrm{PM}_{2.5}$ between 5 p.m. and 12 a.m., thus "reject $H_{0}$,"

Since Mann-Whitney U test does not provide the power, the author decided to perform two-sample $t$ test as well assuming unequal variance (Aspin-Welch Unequal-Variance test), and the power was found to be 0.67 .

\section{Potential Alpha Error}

There are no alpha and beta errors in $\mathrm{CO}_{2}$ levels and with $p=0.84$, the findings suggest no difference in $\mathrm{CO}_{2}$ levels at the peak and off-peak times.

However with $\mathrm{PM}_{2.5}$ there is a difference with 5 p.m. and 12 a.m., the former ( 5 p.m.) being worse to be outside than the latter (12 a.m.). As $p=0.018$, null hypothesis $\left(\mathrm{H}_{0}\right)$ was rejected. The chance that $\mathrm{H}_{0}$ was incorrectly rejected exists and to minimize this, the author suggests that an alpha error could occur if $p$ cut off was set at 0.01 instead of 0.05 , then the finding $p=0.018$ would not be considered statistically significant. In this study $p$ cut off was set to 0.05 . 


\section{Discussion}

The adverse effects of global warming and air pollution have recently been a significant concern for public health authorities, environmental health officers and scientists; Literature about the short-and long term impacts of air pollution on human health has been increasing. Studies have demonstrated that gases and particles emitted from coal combustion as well as from the emissions of motor vehicles in big cities have significantly affected the air quality and caused serious health problems (Tiwary \& Colls 2010). Serious respiratory tract, pulmonary and cardiovascular diseases that are caused by indoor and outdoor environmental air pollution have been reported in those big cities. However many countries have ignored air pollution in order to be able to achieve their economical growth goals, leaving the skylines in their big cities in smog and dust.

In this study, the difference between $\mathrm{CO}_{2}$ levels observed in peak (5 p.m.) and off-peak (12 a.m.) hours has been found statistically not significant $(p$ $=0.84$ ) and the average of the rush hour $\mathrm{CO}_{2}$ levels has been found as $393.8 \mathrm{ppm}$. These results are consistent with the acceptable range for outdoor $\mathrm{CO}_{2}$, 375 to 450 ppm (Schell \& Inthout 2014). When the observed average $\mathrm{CO}_{2}$ level is compared to $5000 \mathrm{ppm}$ recommended by the American Conference of Governmental Industrial Hygienists as the maximum acceptable limit, it can be said that the $\mathrm{CO}_{2}$ level observed in this study, even at peak-hours, does not constitute any risk to public health or the environment (NCCEH 2014).

A growing body of scientific evidence shows that $\mathrm{PM}_{2.5}$ level is higher in rush hours, i.e. pollutants emitted from road vehicles are higher in rush hours, and the results of this study is consistent with the available scientific data. The difference between the $\mathrm{PM}_{2,5}$ concentrations in peak (5 p.m.) and off-peak (12 a.m.) hours has been found statistically significant $(p=0.018)$ and the average of the $\mathrm{PM}_{2.5}$ levels has been found as $15.6 \mu \mathrm{g} / \mathrm{m}^{3}$ during rush hours (5 p.m.). As this level is lower than the BC's 24-hour $\mathrm{PM}_{2.5}$ standard, which is $25 \mu \mathrm{g} / \mathrm{m}^{3}$ (BC Air Quality Objectives 2014), the author concludes, with some hesitations, that the $\mathrm{PM}_{2.5}$ level in Vancouver Downtown does not pose any risk to public health or the environment compared to the levels in many other parts of the world where the situation is worse. Author's hesitations result from four values observed which are higher than the BC limit of $25 \mu \mathrm{g} / \mathrm{m}^{3}$ (32, 78, 38, and 49). These exceeding data points might be associated with some factors which affected the $\mathrm{PM}_{2,5}$ concentration on those days, such as the higher numbers of diesel vehicles, vehicle velocity in the traffic stream, or wind and air flow at that time of period in the area. As these data points caused unequal variance, i.e. skewed distribution, MannWhitney U test was performed to minimize the effect of the outlier data and increase the power of the study.

Although the $\mathrm{PM}_{2,5}$ levels at peak and off-peak hours have been found statistically significant, the average value, as said above, is not at alarming level; however, long term exposures both to $\mathrm{PM}_{2,5}$ and $\mathrm{CO}_{2}$, the author believes, can still cause or at least trigger some pulmonary and cardiovascular diseases as well as infant mortality.

\section{Recommendations}

There is no doubt that air pollution is associated with economic activities and its health impacts are more detrimental in developing countries. Scientists have been cooperating to challenge morbidity and mortality rates by sharing scientific assessments and evidences regarding the environmental causes (e.g. asbestos and tobacco smoke). This can be done in the same way for air pollution.

In order to create a balance between the economic growth and the maintenance of human health, local health authorities should recognize the public health risks and respond to these risks by developing new public health policies that will help reduce the morbidity and mortality caused by air pollution. Governments and national and international agencies should promote and financially support high quality scientific research that addresses these risks and informs public health and environmental policies.

Health care providers, in cooperation with Public Health Authorities, should be responsible for educating all patients suffering either respiratory or cardiovascular diseases, and people who are not suffering these illnesses but considered to be at high risk, such as the elderly, the children, pregnant women, and people with diabetes or immune systemrelated diseases. Information channels and means should be easily accessible and be provided to everyone who are at risk.

From a healthy built environment perspective, to decrease the effect of outdoor air pollution on indoor air quality, the ventilation systems of the buildings can be designed in a way that they can filter the air particles. It has been reported that filters of this kind increase the air quality (Challoner 2014). Moreover, people can be informed and encouraged to use air purifiers with HEPA filters in hospitals and homes (IQAir 2014). Furthermore, hybrid and electric 
vehicles should be encouraged and private vehicles should be preferred only when public transport, cycling, or walking are not available or not attractive choices.

EHOs should keep educating the public regarding the air pollution, be familiar with recent studies about the topic, keep themselves updated on relevant laws and regulations, and be actively involved in research.

And finally, people should learn more and selfeducate themselves about the risks of air pollution and compromise from their excessive use of energy and dependence on personal motor vehicles.

\section{Limitations}

In this study the author explored the $\mathrm{PM}_{2,5}$ and $\mathrm{CO}_{2}$ levels and compared each variable in itself by time (peak vs. off-peak hours). Although the daily wind speeds and temperatures were also recorded, they were not considered as an independent variable. They were not taken into consideration when interpreting the results. As Dockery maintains (2001), the connection of the PM to daily mortality among persons suffering cardiovascular and respiratory illnesses is strong and "not confounded by weather" and its effects are independent of "the effects of other co-pollutants". However, Perrone et al. 2013 argue that $\mathrm{PM}_{2,5}$ level is affected by the air flow in the atmosphere. To verify or oppose either Dockery's or Perrone et al.'s arguments, the author recommends further research (see "Suggestions for Future Studies" below).

As a consequence of the uncertainties in this study, the quantitative results of this study should not be confidently extrapolated to other geographic areas, such as other cities in Canada or abroad. More comprehensive data that takes all other factors, which might have an impact on $\mathrm{CO}_{2}$ and $\mathrm{PM}_{2,5}$ levels, and that is collected in long-term-based research, e.g. 24 hour-monitoring for 6 months, is needed to achieve higher accuracy about the $\mathrm{CO}_{2}$ and $\mathrm{PM}_{2,5}$ levels.

\section{Suggestions for Future Studies}

(i) Further research focusing on (a) other air pollutants that may cause respiratory or cardiovascular diseases as well as lung cancer, either alone or along with $\mathrm{PM}_{2,5}$, and (b) weather conditions, i.e. air flow, wind speed and temperature. The author also recommends long term monitoring of the
$\mathrm{PM}_{2,5}$, e.g. 24 hour-monitoring for 6 months, in order to see if there is a pattern with outliers and increase the power of study.

(ii) Although the results in this study show that the average $\mathrm{CO}_{2}$ level in Vancouver Downtown is below the maximum acceptable concentration limit, $27 \%$ of $\mathrm{CO}_{2}$ in Canada is released from the transport sector (Statistics Canada 2014). Therefore, although the greenhouse gas $\mathrm{CO}_{2}$ does not currently pose a public health concern, its environmental impact should not be underestimated and studies on its possible health effects should continue.

(iii) Monitoring other parameters such as $\mathrm{O}_{3}$, $\mathrm{SO}_{2}, \mathrm{NOx}$, and $\mathrm{PM}_{10}$, because they are also air pollutants having adverse health effects.

(iv) Conducting a survey to determine the knowledge level of affected patients in regards with air pollutants and their health effects, risks due to outdoor activities done during rush hours near the roads, and measures how to avoid these risks.

(v) Exploring the preventive measures (e.g. patient education, air filtration, personal protection, reducing exposures) and treatment alternatives (e.g. antioxidants, vitamins and minerals).

(vi) Examining the synergetic effects of pollutant mixtures (e.g. mixture of PM and ozone).

(vii)Better defining vulnerable populations and exploring their relative levels of exposure to air pollution.

\section{Conclusion}

The data shows that $\mathrm{PM}_{2.5}$ and $\mathrm{CO}_{2}$. levels in Downtown Vancouver do not raise any concern for EHOs and pose no risk to public health or the environment. However, from a public health perspective, the elderly and children, and pregnant residents of these areas or those who suffer from pulmonary or cardiovascular illnesses should avoid staying outside or do outdoor activities during rush hours, if possible, in order to reduce the risks of being exposed to some chronic effects of these pollutants. On the other hand, as the $\mathrm{PM}_{2.5}$ levels are generally quite low and $\mathrm{CO}_{2}$ levels are within the acceptable levels, the author believes that the air quality programs that are implemented in the area are successful. 
There is an essential need for more diverse data and more solid evidence on the health effects of air pollution, especially in economically and socially active, industrialized urban settings, that will inform more comprehensive, supportive and stricter policies to reduce all kinds of gaseous substances, including particulate matters and greenhouse gases released from the combustion engines of motor vehicles as a result of burning fossil fuels.

\section{Acknowledgement}

I would like to express my special appreciation and thanks to my instructor Dr. Helen Heacock who has been a tremendous adviser for me. I would like to thank her for her invaluable support and guidance during my research. I would also like to thank $\mathrm{Mr}$. Fred Shaw for his patience, technical support and assistance on how to use the equipment necessary to complete this study.

\section{Competing Interest}

The authors declare that they have no competing interests.

\section{References}

BC Air Quality Objective. (2014, April). Provincial Ambient Air Quality Criteria for $\mathrm{PM}_{2.5}$ :Ministry Intentions Paper. Environmental Quality Branch. Ministry of Environment. Retrieved from http://www.bcairquality.ca/reports/pdfs/pm25criter ia_summary.pdf

Brook, R.D., Franklin, B., Cascio, W., Hong, Y., Howard, G., Lipsett, M., Luepker, R., Mittleman, M., Samet, J., Smith, S.C. Jr, \& Tager, I. (2004). Air pollution and cardiovascular disease: a statement for healthcare professionals from the expert panel on population and prevention science of the american heart association. Circulation, 109 (21):2655-2671. Retrieved from

http://circ.ahajournals.org/content/109/21/2655.ful 1?ijkey=24f5d6401dfd1b26da1c3449196c483c88d f70d1[2014 April 3].

Brook, R.D., Rajagopalan, S.,Pope III, C.A., Brook, J.R., Bhatnagar, A., Diez-Roux, A.V., Holguin,F., Hong, Y., Luepker, R.V., Mittleman, M.A., Peters, A., Siscovick, D., Smith, S.C. Jr, Whitsel, L., \& Kaufman, J.D. (2010). Particulate matter air pollution and cardiovascular disease: an update to the scientific statement from the American heart association. Circulation. 121: 2331-2378. DOI:10.1161/CIR.0b013e3181dbece1. Retrieved from http://circ.ahajournals.org/content/121/21/2331.ful 1.pdf+html. [2014 April 3].

Bulkeley, H. (2013). Cities and Climate Change.(pp.8). Abingdon, Oxon: Routledge.

Burt, E., Orris, P., \& Buchanan, S. (2013). Scientific evidence of health effects from coal use in energy generation. University of Illinois, Chicago School of Public Health, Illinois, USA. Retrieved from http://noharmglobal.org/sites/default/files/documentsfiles/828/Health_Effects_Coal_Use_Energy_Gene ration.pdf.[2014 April 3].

Canadian Environmental Protection Act, (2014, April). Retrieved from http://www.oas.org/dsd/fida/laws/legislation/canad a/canada_epa-1999.pdf.

Challoner, A., Gill, L., (2014, April). Indoor / outdoor air quality relationship in urban commercial buildings: Dublin case studies. Proceedings of the ITRN2011. Retrieved from http://www.itrn.ie/uploads/sesA3_72.pdf.

Cleaner Gasoline Regulation.(2014, April). B.C. Reg. 498/95. Retrieved from http://www.bclaws.ca/EPLibraries/bclaws_new/do cument/ID/freeside/14_498_95.

Coccola C, (2014, January) Ministry of Environment, Inventory of Air Quality Bylaws in BC 2011, Air pollution Law and Legislation. Retrieved from: http://www.bcairquality.ca/reports/pdfs/bylaws2011.pdf.

Cohen, A.J., Anderson, H.R., Ostro, B., Pandey, K.D., Krzyzanowski, M., Künzli,N., Gutschmidt, K., Pope, A., Romieu, I., Samet, J.M. \& Smith, K. (2005). The global burden of disease due to outdoor air pollution. Journal of Toxicology and Environmental Health. 68: 13-14. 1301-1307. DOI:10.1080/15287390590936166.Retrieved from http://www.tandfonline.com/doi/full/10.1080/1528 7390590936166\#.U1bDLle9Z. [2014 April 4].

D’Amato, G.,Baena-Cagnani, C.E., Cecchi, L., Annesi-Maesano, I., Nunes, C., Ansotegui, I., D’Amato, M., Liccardi, G., Sofia, M. \& Canonica, W.G.(2013). Multidisciplinary Respiratory Medicine. 2013, 8:12, 1-3. Retrieved from http://www.biomedcentral.com/content/pdf/20496958-8-12.pdf. [2014 April 3].

Dockery, D.W. (2001) Epidemiologic evidence of cardiovascular effects of particulate air pollution. Environmental Health Perspectives. 109 : 4, 483486. Retrieved from 
http://www.ncbi.nlm.nih.gov/pmc/articles/PMC12 40569/pdf/ehp109s-000483.pdf. [2014 April 3].

DustTrak Aerosol Monitor. (2014, April). Model 8520 Operation and Service Manual Retrieved from

http://www.hotzonewv.com/PDF/DustTrakManual .pdf.

Enviro-Equipment. (2014, April), TSI Q-Trak. Retrieved from

http://www.enviroequipment.com/rentals/qtrac.html.

EH Manitoba. (2014, April). Environmental Health: Manitoba Health. Retrieved from http://www.gov.mb.ca/health/publichealth/environ mentalhealth/index.html.

Environmental Health UK.(2014, April).Report on Turnkey Osiris Particle Results at the Halkett Place and Howard Davis Park Sites in Jersey for 2012. Retrieved from http://www.gov.je/SiteCollectionDocuments/Gove rnment\%20and\%20administration/R\%20Report\% 20on\%20Turnkey\%200siris\%20Particle\%20Resul ts $\% 20$ Halkett $\% 20$ Place $\% 20$ and $\% 20$ Howard\%20D avis\%20Park\%20Sites\%2020131211\%20MM.pdf.

Environmental Management Act (2014, April): British Columbia,Canada. Retrieved from http://www.bclaws.ca/civix/document/id/complete/ statreg/03053_00

http://www.bclaws.ca/civix/document/LOC/compl ete/statreg/--\%20E\%20-

/Environmental\%20Management\%20Act\%20[SB C\%202003]\%20c.\%2053/00_Act/03053_06.xml.

Farmer, G. T.\& Cook, J. (2013). Climate Change Science: A Modern Synthesis, Vol 1, (pp. 199200), Springer.

Fajersztajn, L., Veras, M., Barrozo, L.V. \& Saldiva, P. (2013). Air pollution: a potentially modifiable risk factor for lung cancer. Nature Reviews/ Cancer. 13: 674-678. Retrieved from

http://apostilas.cena.usp.br/Regina/Disciplinas\%20 $\mathrm{P} \% \mathrm{C} 3 \% \mathrm{~B} 3 \mathrm{~s}-$

Gradua\%C3\%A7\%C3\%A3o/Quimica\%20Ambien tal/Apresenta\%C3\%A7\%C3\%B5es\%20Semin\%C $3 \%$ A1rios/Air\%20Pollution\%20Nature \%20Cancer \%20Reviews\%20213.pdf. [2014 April 4].

Fenger, J. \& Tjell, J.C. (2009). Air pollution: from a local to a global perspective. (pp.132-133). Lyngby, Denmark: Polyteknisk Forlag.
Franklin, P., Kusel, M. (2013). Environmental contributions to childhood asthma. Journal of Environmental Immunology and Toxicology. 1:2, 53-57. Retrieved from http://www.stmconnect.com/sites/default/files/201 30722131828.pdf. [2014 April 3].

Greenhouse Reduction Act (2014, April). Bill 392008. Retrieved from http://www.leg.bc.ca/38th4th/amend/gov392.htm\#section 24 .

Gan, W.Q., FitzGerald, J.M., Carlsten, C., Sadatsafavi, M. \& Brauer, M. (2013). Associations of Ambient Air Pollution with Chronic Obstructive Pulmonary Disease Hospitalization and Mortality. American Journal of Respiratory and Critical Care Medicine. 187:7, 721-727. Retrieved from http://www.atsjournals.org/doi/pdf/10.1164/rccm.2 01211-2004OC. [2014 April 3].

IQAir.(2014, April). Air pollution linked to hospital visits; air purifiers may help. Retrieved from http://www.iqair.com/newsroom/2012/airpollution-linked-to-hospital-visits-air-purifiersmay-help.

Haines, A., McMichael, A.J., Smith, K.R., Roberts, I., Woodcock, J., Markandya, A., Armstrong, B.G., Campbell-Lendrum, D., Dangour, A.D., Davies, M., Bruce, N., Tonne, C., Barrett, M., Wilkinson, P. (2009). Public health benefits of strategies to reduce greenhouse-gas emissions: overview and implications for policy makers. The Lancet. 374: 9707, 2104-2114.

DOI:10.1016/S0140-6736(09)61759-1. Retrieved from

http://www.thelancet.com/journals/lancet/article/PI IS0140-6736(09)61759-1/fulltext\#article_upsell.

Huang, M.Q., Zhang, W.J., Hao, L.Q., Wang, Z.Y., Zhao, W.W., Gu, X.J. \& Fang, L. (2008). Low molecular weight and oligomeric components in secondary organic aerosol from the photooxidation pf p-xylene. Journal of Chinese Chemical Society. 55:2, 456-463. DOI: 10.1002/jccs.200800068. Retrieved from http://onlinelibrary.wiley.com/doi/10.1002/jccs.20 0800068/pdf. [2014 April 3]

Laumbauch, R.J., Kipen, H.M. (2012). Respiratory health effects of air pollution: Update on biomass smoke and traffic pollution. J. Allergy Clin. Immunol. 129:1, 3-10. Retrieved from http://download.journals.elsevierhealth.com/pdfs/j ournals/0091-6749/PIIS0091674911018264.pdf.

Montzka, S.A., Dlugokencky E. J. \& Butler, J. H. (2011). Non- $\mathrm{CO}_{2}$ greenhouse gases and climate 
change. Nature. 476: 43-50.

DOI:10.1038/nature10322. Retrieved from http://www.indiaenvironmentportal.org.in/files/file /CO2\%20greenhouse.pdf. [2014 April 4].

NCCEH. National Collaborating Centre for Environmental Health. (2014, January). Where does $\mathrm{CO}_{2}$ come from? Retrieved from http://www.ncceh.ca/professional_development/pr actice_questions/co2_indoor_air\#physiological_re sponses.

Perrone, M.R.,Becagli,S.,Garcia Orza, J.A.,Vecchi,R. ,Dinoi,A.,Udisti, R.Cabello,M. (2013).The impact of long range transport on $\mathrm{PM}_{1}$ and $\mathrm{PM}_{2.5}$ at a central Mediterranean site. Atmospheric Environment., 71, 176-186. Retrieved from http://seneca.umh.es/pdf/long_range_transport_P M25PM1_Lecce-AE_2013-Perrone_et_al.pdf.

Popa, M.E., Vollmer, M.K., Jordan, A., Brand, W.A., Pathirana, S.L., Rothe, M., Rockmann, T. (2014). Vehicle emissions of green house gases and related tracers from a tunnel study: $\mathrm{CO}: \mathrm{CO}_{2}$, $\mathrm{N}_{2} \mathrm{O}: \mathrm{CO}_{2}, \mathrm{CH}_{4}: \mathrm{CO}_{2}, \mathrm{O}_{2}: \mathrm{CO}_{2}$ ratios, and the stable isotopes ${ }^{13} \mathrm{C}$ and ${ }^{18} \mathrm{O}$ in $\mathrm{CO}_{2}$ and $\mathrm{CO}$. Atmospheric Chemistry and Physics. 14, 2105-2123. Retrieved from http://www.atmos-chemphys.net/14/2105/2014/acp-14-2105-2014.pdf.

Q-Trak. (2014, April). Q-Trak Monitor. Model 8550/8551. Operation and Service Manual 1980197, Revision M. Retrieved from http://www.tsi.com/uploadedFiles/_Site_Root/Pro ducts/Literature/Manuals/1980197M.pdf.

Ruckerl, R., Schneider, A., Breitner, S., Cyrys, J., \& Peters, A. (2011). Health effects of particulate air pollution: A review of epidemiological evidence. Inhalation Toxicology. 23 (10): 555-92. DOI:10.3109/08958378.2011.593587. Retrieved from http://www.researchgate.net/publication/51592640 _Health_effects_of_particulate_air_pollution_A_r eview_of_epidemiological_evidence.[2014 April 3].

Schell,M., Inthout, D.(2014, April).Ventilation: Demand Control Ventilation Using $\mathrm{CO}_{2}$. ASHRAE Journal. Retrieved from http://www.airtest.com/support/reference/article2. pdf.

Statistics Canada. (2014, April). Government of Canada: Introduction. Retrieved from http://www.statcan.gc.ca/pub/16-001m/2010012/part-partie1-eng.htm.

Tiwary, A. \& Colls, J. (2010). Air pollution: measurement, modelling and mitigation. (3rd Ed.). (pp. 359-361). New York, NY: Routledge.
Woodgears. (2014, January). Dylos Air Quality Monitor. Retrieved from http://woodgears.ca/dust/dylos.html.

Woolsey, L. (2013). Particulate Matter: An Overview Quebec, Environment Canada. p. 1. ENVH 7002., Outdoor Air Quality Coursepack, Burnaby, BC: British Columbia Institute of Technology. 